\title{
ФОРМУВАННЯ МЕТОДИЧНОЇ КОМПЕТЕНТНОСТІ МАЙБУТНЬОГО ВЧИТЕЛЯ ШЛЯХОМ ВИКОРИСТАННЯ ПРОЕКТНОЇ ТЕХНОЛОГІЇ
}

\author{
Ірина Вікторенко \\ кандидат педагогічних наук \\ доцент кафедри теорії і практики початкової освіти \\ ДВНЗ «Донбаський державний педагогічний університет» \\ м. Слов'янськ, Україна \\ viktorenko2210@gmail.com
}

Анотація. Стаття присвячена проблемі методичної підготовки студентів до здійснення професійної діяльності в умовах становлення Нової української початкової школи. Запровадження в освітній процес вишу проектних технологій авторка вважає одним із чинників, що позитивно впливає на його ефективність.

Надано сутнісну характеристику ключових понять дослідження: «методична компетентність учителя природознавства початкових класів», «проектний метод навчання». Виняткову увагу приділено змодельованій авторкою технологічній карті проектної діяльності «Україна на карті світу. Найближчі сусіди нашої держави», до якої залучались студентитретьокурсники. Описано механізм і особливості організації та реалізації проектної технології в процесі навчання природничої освітньої галузі. Особливий акцент зроблено на тому, що подібна робота $\epsilon$ надійною в підготовці до запровадження аналогічної роботи в 4-му класі, коли молодші школярі вивчають тему «Природа України».

Зроблено висновки про доцільність застосування методу проектів у виші; він виступає дієвим засобом формування методичної компетентності майбутнього вчителя початкових класів, розвитку його пізнавального інтересу, самостійності, інтелектуальних здібностей, становленню професійно важливих особистісних рис. Він дає змогу кожному студенту залучитися до активного пізнавального процесу, дозволяє виявити здібності в груповій співпраці, підвищує мотивацію до навчання.

Ключові слова: методична підготовка студентів; удосконалення підготовки вчителів початкових класів; формування предметної природознавчої компетентності молодших школярів; викладач вищого навчального закладу; методична компетентність учителя природознавства початкових класів; Нова українська школа; проектний метод навчання; творча особистість; розвиток індивідуальності особистості школяра; компетентнісне навчання; технологічна карта проектної діяльності.

Школа повинна перетворитися з супермаркету, де роздають «заморожені ідеї», у місие, де можна шукати і самостійно знаходити нові знання. Карл Ренсом Роджерс

Постановка проблеми в загальному вигляді. Практика підготовки майбутнього вчителя початкових класів у вищій школі вимагає розв'язання проблеми формування методичної компетентності як необхідного компонента його професійної готовності до формування предметної природознавчої 
компетентності молодших школярів. У дослідженні представлено авторське розуміння педагогічної сутності поняття «методична компетентність учителя природознавства початкових класів»: «теоретична і практична готовність його до формування предметної природознавчої компетентності молодших школярів під час навчання освітньої галузі «Природознавство», що виявляється у сформованості предметно-теоретичних (природничих), психолого-педагогічних i дидактико-методичних знань i вмінь, досвіду їхнього застосування $\mathrm{i}$ особистісно значущих якостей особистості; здатності вчителя до організації навчально-виховного процесу відповідно до сучасних вимог підготовки молодших школярів на засадах особистісно зорієнтованого, технологічного i компетентнісного підходів; спроможності результативно діяти, ефективно розв'язувати методичні задачі різного роду складності, що виникають під час навчання молодших школярів природознавства; готовності виконувати різноманітні професійно-педагогічні функції під час навчання молодших школярів змісту початкової загальної освіти, що визначається навчальним предметом та освітньою галуззю «Природознавство» для успішної продуктивної педагогічної діяльності, усвідомлюючи їі соціальну значущість і особисту відповідальність за результати цієї діяльності, необхідність їі постійного вдосконалення» [1].

Одним із ключових принципів нового Держаного стандарту початкової загальної освіти $€$ «забезпечення радості пізнання через дослідницьке та проектне навчання» [3]. У зв’язку 3 цими програмними вимогами курсу «Природознавство» передбачено залучення школярів до проектної діяльності, яка «у сучасній початковій школі втілює ідею індивідуалізації навчального процесу та розвивального навчання. Саме в процесі проектної діяльності на уроках природознавства формуються міжпредметні (дослідницька, формування наукової картини світу) та ключові (уміння вчитися, інформаційнокомунікативна, соціальна, громадянська, загальнокультурна, здоров'язбережувальна) компетентності» [2].

Тож стрижневою вимогою забезпечення впровадження в освітній простір початкової школи нових Державних стандартів $\epsilon$ організація навчальновиховного процесу на засадах компетентнісної освіти, тісно пов'язаної з такими підходами до навчання, як особистісно орієнтований (бо потребує трансформації змісту освіти, перетворення його з моделі для «всіх» на суб’єктивні надбання одного учня, що їх можна виміряти) та діяльнісний (адже може бути реалізований і перевірений лише в діяльності, тобто в процесі виконання конкретним учнем певного комплексу дій). Компетентнісне навчання забезпечує здатність і готовність молодшого школяра знаходити потрібну інформацію, міркувати, критично і системно мислити, приймати самостійні аргументовані рішення, робити та обгрунтовувати висновки, брати участь у навчальному діалозі, логічно доводити позицію, готувати повідомлення. Зазначені складові навчального процесу максимально стимулюють молодших школярів не стільки 
до засвоєння суми природничо-наукових знань, скільки до формування вмінь здобувати ці знання, забезпечують розвиток особистості, здатної бути не просто носієм і транслятором знань, але і його активним, самоорганізованим суб'єктом, який уміє самостійно знаходити та відкривати знання, спираючись на особистісний освітній досвід.

Важливу роль у формуванні творчої особистості молодшого школяра відіграє компетентнісно орієнтований учитель. Створити ж відповідні умови для підготовки такого вчителя покликаний викладач вишу.

Ураховуючи актуальність проблеми методичної підготовки студентів до виконання професійної діяльності в системі сучасного освітнього процесу Нової української початкової школи, запровадження в навчальний процес вишу проектних технологій навчання вважаємо одним із чинників, який позитивно вплине на їі ефективність. Така практика підготовки майбутнього вчителя забезпечить розв'язання проблеми формування методичної компетентності як необхідного компонента його професійної готовності до формування предметної природознавчої компетентності молодших школярів.

Аналіз останніх досліджень i публікацій. Проблему підготовки майбутніх фахівців до педагогічної діяльності шляхом застосування проектних технологій розробляли: Л. Василевська, Р. Галустов, Н. Довмантович, Н. Зубов, С. Ізбаш, Л. Козак, Л. Лук’янова, К. Мелашенко, О. Нікуліна, М. Пелагейченко, Т. Подобєдова, Є. Полат, Т. Сілакова, С. Сисоєва, М. Уйсімбаєва, 3. Шацька, С. Шевцова та ін.

Проведений аналіз найпоширеніших серед науковців визначень методу проектів дає підстави для висновку про відсутність чіткої парадигми його трактування і дозволяє інтерпретувати його як особистісно орієнтований метод навчання, заснований на самостійній діяльності учнів щодо розробки проблеми й оформлення iï практичного результату (С. Пілюгіна); одну з інноваційних технологій навчання і виховання, яка поєднує теоретичні знання та їхнє практичне застосування для розв'язання конкретних життєвих чи професійних проблем (Л. Козак); систему навчання, гнучку модель організації навчального процесу, орієнтовану на творчу самореалізацію особистості завдяки розвитку іiі інтелектуальних і фізичних можливостей, вольових якостей і творчих здібностей у процесі створення під контролем учителя нових товарів і послуг, які мають суб'єктивну або ж об'єктивну новизну, а також практичну значущість (Р. Галустов і Н. Зубов); педагогічну технологію, що передбачає певну сукупність навчально-пізнавальних прийомів, які дають змогу розв'язати ту чи ту проблему в результаті самостійних дій учнів з обов'язковою презентацією цих результатів (К. Мелашенко); спосіб досягнення дидактичної мети через детальну розробку проблеми (технології), що повинна завершитися цілком реальним, відчутним практичним результатом, оформленим тим чи тим чином (Є. Полат).

Незважаючи на активні теоретичні дослідження в цій сфері, залишається невирішеним питання щодо формування компетентнісно орієнтованого вчителя, 
готового до формування предметної природознавчої компетентності молодших школярів шляхом запровадження в систему навчання вишу проектної технології.

Формулювання мети. Мета статті - розкрити особливості формування методичної компетентності майбутнього вчителя засобами проектної діяльності.

Результати дослідження. Як свідчать спостереження за діяльністю студентів під час проходження виробничої практики, а також спілкування 3 учителями-наставниками початкової ланки та випускниками, останні відчувають труднощі в застосуванні отриманих знань, умінь і навичок у професійній діяльності. Такий факт, безперечно, є однією з проблем сучасної вищої освіти. Умінню застосовувати отримані теоретичні знання на практиці потрібно навчати, воно не може з'явитися само собою. Уважаємо, що впровадження в навчальний процес вищої школи методу проектів $є$ вкрай необхідним для вирішення окресленої проблеми.

Пропонуємо технологічну карту проектної діяльності «Україна на карті світу. Найближчі сусіди нашої держави», до якої залучались студентитретьокурсники. Ї̈̈ організація і реалізація виступає надійною підготовчою роботою до запровадження аналогічної роботи в 4-му класі, коли молодші школярі вивчають тему «Природа України» (Державні вимоги до навчальних досягнень учня/учениці: знає розташування України на карті; правила збереження природи в рідному краї; використовує географічну карту України й рідного краю для розв'язання навчальних і життєвих ситуацій).

Tuп проекту:

- за домінувальною діяльністю - інформаційно-творчий;

- за предметно-змістовою галуззю - надпредметний;

- за характером координачії - 3 прихованою координацією;

- за кількістю учасників - груповий;

- за тривалістю - середньої тривалості (місяць);

Учасники проекту: студенти.

Провідна проблема: освоєння студентами механізму організації та реалізації проектної технології в процесі навчання природничої освітньої галузі; дізнатися якомога більше про країни, які межують із нашою державою.

Мета проекту: формування навичок організації і проведення проектної діяльності; поглибити знання про Україну як одну з країн на карті світу, про найближчих сусідів України; провести дослідницьку роботу про населення, традиції, звичаї країн-сусідів; розвивати в студентів бажання творчого пошуку, уміння досліджувати матеріал, робити висновки; виховувати патріотизм і поважне ставлення до громадян інших країн; привернути увагу студентів до проблеми виховання патріотизму в молодих громадян нашої країни.

Завдання проекту:

- виявлення особливостей та результатів упровадження проектних технологій у навчальний процес сучасної початкової школи з погляду як учителя, так і учня; 
- розвиток у студентів уміння користуватися дослідницькими прийомами: ставити цілі, планувати й організовувати власну навчальну діяльність за темою проектної роботи, аналізувати 3 різних позицій, узагальнювати, систематизувати і робити висновки;

- розповсюдження інформації про країни, які межують з Україною;

- формування вмінь працювати в групі;

- формування пізнавальних мотивів студентів;

- розширення можливостей навчання та самонавчання;

- розвиток креативності, творчих здібностей студентів;

- формування в студентів комунікативних навичок.

Обладнання, інструменти, матеріали: комп'ютери 3 широкою периферією, виходом в Internet; сканер для зчитування інформації; принтер; ксерокс; проектор; екран; фізична карта України; лепбуки для зразка.

Змістові питання:

1. Україна на карті світу.

2. Найближчі сусіди України (Росія, Білорусь, Польща, Словаччина, Угорщина, Молдова, Румунія).

3. Площа та населення країн-сусідів.

4. Промисловість країн.

5. Звичаї та народні традиції країн.

Очікувані результати (перелік умінь і навичок, яких набувають студенти після завершення реалізачії проекту):

- уміння користуватися дослідницькими прийомами: ставити цілі, планувати й організовувати власну навчальну діяльність за темою проектної роботи (розробляти план загалом та конкретних дій, вибір способів збору інформації, форми звіту), аналізувати здобуту інформацію, узагальнювати i систематизувати їі, робити висновки;

- уміння створювати продукт проекту згідно з критеріями і презентувати його відповідно до обраної форми (готовність розповсюджувати інформації про країни, які межують з Україною);

- отримання досвіду публічного виступу під час захисту проекту;

- набуття навичок давати творчу оцінку результатам проектної діяльності та особистим навчальним досягненням тощо;

- уміння працювати в групі;

- засвоєння чіткої схеми діяльності на всіх етапах роботи над проектом; готовність переносити здобуті вміння і навички щодо планування й організації діяльності, наукові методи пізнання, відпрацьовані на всіх етапах роботи над проектом, на навчальну діяльність молодших школярів на уроках природознавства;

- готовність до виховання патріотизму і поважного ставлення до громадян інших країн; готовність до виховання патріотизму в майбутніх громадян нашої країни. 
Форма продукту проектної діяльності (форма презентачії остаточного продукту): інтерактивна папка - лепбук; інтерактивний плакат; портфоліо проекту (папка для збору всіх робочих матеріалів); відеофільм; рекламний ролик; театральна постанова; мандрівка, екскурсія; мультимедійний продукт; інформаційний стенд; прес-конференція; телепередача; Web-сайт; подорож, екскурсія; гра (рольова, ділова); виставка; журнал; газета; підбір кросвордів, мультфільмів, легенд; доповідь.

Виконання проекту передбачало кілька послідовних дій: niдготовчий, пошуковий, технологічний (дослідно-творчий) $і$ заключний етапи.

Підготовчий етап.

1. Створення робочих груп.

2. Вибір і обгрунтування теми проекту.

3. Постановка завдань, визначення мети, етапів роботи.

4. Розподіл завдань.

Технологічний етап.

1. Добір інформації, иї аналіз, систематизація.

2. Проміжний контроль, консультації з керівником проекту.

3. Оформлення матеріалів, написання доповіді.

Заключний етап.

1. Презентація.

2. Оцінка й самооцінка результатів дослідження.

На підготовчому emani виконання проекту було визначено стратегію діяльності: вибір теми, типу проекту, формулювання провідної проблеми та передбачуваного кінцевого результату, розроблення плану проекту, формування творчих груп, ознайомлення кожної групи із завданням, визначення шляхів пошуку інформації.

Цінним на зазначеному етапі було ознайомлення студентів із критеріями оиінки якості виконаного проекту:

1. Необхідна і достатня глибина проникнення в проблему, залучення знань $з$ інших областей.

2. Новизна й оригінальність отриманої інформації, іiі адекватність тематиці, що вивчається.

3. Активність кожного учасника проекту відповідно до його індивідуальних можливостей.

4. Колективний характер рішень, що приймаються; характер спілкування і взаємодопомоги, взаємодоповнювання учасників проекту.

5. Стислість, артистизм і виразність виступу.

6. Цікаві способи подання результатів дослідження.

7. Доречне унаочнення доповіді.

8. Якість оформлення матеріалів презентації.

9. Уміння відповідати на питання опонентів, лаконічність i аргументованість відповідей кожного члена групи. 
Для забезпечення координування ходу виконання творчого проекту в кожній проектній групі зі складу студентів було обрано керівників, які виконували такі обов'язки: видача групам студентів завдань проекту, консультації студентів під час дослідно-творчої роботи, складання плану презентації, вирішення організаційних питань.

Результат niдготовчого етапу: створення плану роботи над проектом.

Метою другого - технологічного етапу - було виконання проектних завдань у групах, завершення етапу накопичення інформації, уточнення кінцевого продукту проекту та початок його оформлення.

Результат технологічного етапу: узагальнення зібраної інформації з теми проекту.

Заключний етап дослідницької роботи був присвячений оформленню висновків і результатів, уточненню форми презентації остаточного продукту проекту.

Результат заключного етаnу: психологічна та змістова готовність студентів до захисту; підготовка презентації продуктів проектної діяльності до теми «Найближчі країни-сусіди України» (доповіді, презентації, інтерактивні плакати, інтерактивні папки - лепбуки «Біловезька пуща - найбільший заповідник у Євпорі», «Татри - найвищий гірський хребет у Карпатах» тощо, розробки кросвордів «Дивні і цікаві факти країн-сусідів України», добірка мультфільмів, легенд тощо).

Для оцінки проекту зі складу студентів була обрана експертна рада, яка мала на меті констатувати якість виконаних завдань, уміння доповісти про дослідження, доречно унаочнити доповідь.

Задля закріплення отриманих знань, акцентування уваги на ключових аспектах проблеми, створення необхідних умов, які сприяли підтримці активності студентів, керівниками груп для аудиторії за матеріалами доповідей було підготовлено бліц-турніри. Нижче наведено кілька запитань бліц-турніру «Географічні ерудити» (проект «Польща - це серце Європи):

- Давні столиці Польщі... (Краків, Гнєзно, Познань, Люблін).

- Назва країни походить від ... (назви племені «поляни», що означає «люди, що живуть у відкритих полях»).

- За національним складом Польща... (найбільш мононаціональна - згідно 3 офіційною статистикою перепису населення, 93,52\% людей уважають себе корінними поляками).

- Найвідоміший національний парк Польщі... (Біловезька ІІуща).

- Кам'яновугільний басейн Польщі (переважно в Польщі, але частково в Чехії), що займає I місце в Свропі... (Верхньосілезький).

- Що називають «сонячним каменем»... (бурштин).

- Відомий польський композитор і піаніст ... (Фридерик Шопен).

- Факти, які будуть цікавими для молодших школярів - це... (у центрі Варшави $є$ вулиця Вінні-Пуха; найпопулярнішою кличкою собак у Польщі $\epsilon$ 
Бурек; поляки - одна з небагатьох націй, де донині прийнято, щоб чоловіки при зустрічі цілували руку жінкам тощо).

Висновки 3 дослідження і перспективи подальших розвідок у цьому напрямі. Як свідчить досвід власної практичної діяльності й теоретичних досліджень, запровадження проектної технології у виші дає можливість кожному студенту залучитися до активного пізнавального процесу, реалізувати свої можливості, інтелектуальні спроможності для досягнення певної цілі, дозволяє виявити здібності в груповій співпраці. У роботі над спільними проектами навіть найменш сміливі студенти розкриваються, відчувають упевненість у власних силах, що є могутнім стимулом до праці, до творчості. Така технологія, з одного боку, допомагає виробити в майбутніх спеціалістів навички пошуководослідницької діяльності, а 3 іншого - через власну практичну діяльність засвоїти механізм організації та реалізації проектної технології під час навчання молодших школярів природничої освітньої галузі.

Отже, можна стверджувати, що проектна діяльність у виші $є$ дієвим засобом формування методичної компетентності майбутнього вчителя початкових класів, під час опанування якої відбувається становлення професійно важливих якостей фахівця, які $\epsilon$ затребуваними сучасним суспільством i вимогами Нової української школи.

\section{СПИСОК ВИКОРИСТАНИХ ДЖЕЕРЕЛ}

1. Вікторенко, I. (2017). Методична компетентність учителя початкових класів у навчанні природознавства молодших школярів. Теоретичний аспект. Духовність особистості: методологія, теорія і практика № 2 (77), 52-61.

2. Навчальні програми для $1-4$ класів. (б.д.). mon.gov.ua. Взято 3 https://mon.gov.ua/ua/osvita/zagalna-serednya-osvita/navchalni-programi/navchalni-programi-dlyapochatkovoyi-shkoli.

3. Новий державний стандарт початкової загальної освіти. (2017). Всеукраїнська серпнева конференція. Взято 3 http://nus.org.ua/wpcontent/uploads/2017/08/NewSchool_Presentation-final_18-08-2017.pdf.

\section{ФОРМИРОВАНИЕ МЕТОДИЧЕСКОЙ КОМПЕТЕНТНОСТИ БУДУЩЕГО УЧИТЕЛЯ ПУТЕМ ИСПОЛЬЗОВАНИЯ ПРОЕКТНОЙ ТЕХНОЛОГИИ}

\section{Ирина Викторенко}

кандидат педагогических наук

доцент кафедры теории и практики начального образования

ГВУЗ «Донбасский государственный педагогический университет»

г. Славянск, Украина

viktorenko2210@gmail.com

Аннотация. Статья посвящена проблеме методической подготовки студентов к осуществлению профессиональной деятельности в условиях становления Новой украинской 


\title{
I. ВІКТОРЕНКО
}

Формування методичної компетентності майбутнього вчителя шляхом використання проектної технології

начальной школы. Внедрение в учебный процесс вуза проектных технологий автор считает одним из факторов, который положительно влияет на их эффективность.

Актуальность проблемы определяется общественными требованиями к формированию в системе современного образовательного пространства личности, которая в отличие от человека-исполнителя, которая могла бы самостоятельно и нестандартно мыслить, смело генерировать оригинальные идеи, конструировать собственную жизненную стратегию.

Предоставлена сущностная характеристика ключевых понятий исследования: «методическая компетентность учителя естествознания начальных классов», «проектный метод (инновационная технология, система, обучение модель, педагогическая технология, способ достижения дидактической цели) обучения». Исключительное внимание уделено смоделированной технологической карте проектной деятельности «Украина на карте мира. Ближайшие соседи нашего государства», к которой привлекались студенты-третьекурсники. Описан механизм и особенности организации и реализации проектной технологии в процессе обучения естественной образовательной отрасли. Особый акцент поставлен на потом, что ее организация и реализация выступает надежной подготовительной работой к внедрению аналогичной работы в 4-м классе, когда младшие школьники изучают тему «Природа Украины».

Сделаны выводы о целесообразности применения метода проектов в вузе; он выступает действенным средством формирования методической компетентности будущего учителя начальных классов, развития его познавательного интереса, самостоятельности, интеллектуальных способностей, становлению профессионально важных личностных черт. Он позволяет каждому студенту приобщиться к активному познавательному процессу, позволяет выявить способности к групповому сотрудничеству, повышает мотивацию к обучению.

Ключевые слова: методическая подготовка студентов; совершенствование подготовки учителей начальных классов; формирование предметной естественнонаучной компетентности младших школьников; методическая компетентность учителя естествознания начальных классов; преподаватель высшего учебного заведения; Новая украинская школа; проектный метод (инновационная технология, система, обучение модель, педагогическая технология, способ достижения дидактической цели) обучения; творческая личность; развитие индивидуальности личности школьника компетентностное обучение; технологическая карта проектной деятельности.

\section{FORMING THE FUTURE TEACHER'S METHODOLOGICAL COMPETENCE BY USING THE PROJECT TECHNOLOGY}

\author{
Iryna Viktorenko \\ Candidate of Pedagogical Sciences, Associate Professor of Primary \\ Education Theory and Practice Department \\ SHEE "Donbas State Pedagogical University" \\ Sloviansk, Ukraine \\ viktorenko2210@gmail.com
}

\begin{abstract}
The article is devoted to the problem of the students' methodological training for the professional activity in the context of forming the New Ukrainian primary school. The author considers the implementing of the project technology into the educational process as one of the factors that positively influences its effectiveness.
\end{abstract}

Професіоналізм педагога: теоретичні й методичні аспекти. - Вип. 8. - Слов’янськ, 2018. 


\section{I. ВІКТОРЕНКО}

Формування методичної компетентності майбутнього вчителя шляхом використання проектної технології

The relevance of the problem is determined by the social requirements for the formation of a creative personality in the system of the modern educational space, which, unlike the executor person, could independently and unconventionally think, boldly generate original ideas, construct his own life strategy.

The leading idea was embodied in one of the priorities of the New Ukrainian School: the comprehensive development of the individual's personality of the student, his talents, abilities, competencies, creativity, curiosity. New values and guidelines for education determine the choice of teaching methods, among which the benefits are provided by active and interactive pedagogical technologies. A vivid example is the project activity, which allows the most successful implementation of the competence training, based on activity and personality oriented approaches.

The study draws attention to the fact that an important role in the formation of a young person's creative personality is played by a competently oriented teacher who is ready to form the primary schoolchildren's subject competence in Nature Study. A university teacher is claimed to create the appropriate conditions for such preparation.

The author gives an essential characteristic of the key concepts of the study - "methodological competence of primary school teachers of Nature Study", "project method of teaching". Exclusive attention is paid to the technological map of the project activity "Ukraine on the map of the world. The nearest neighbours of our country" simulated by the author, which attracted the third-course students. The mechanism and peculiarities of the organization and implementation of the project technology into the process of studying the natural educational branch are described. Particular emphasis is placed on the fact that such work is reliable in preparation for the conducting of a similar work in the 4th grade, when primary schoolchildren study the topic "Nature of Ukraine".

Conclusions about the expediency of using the project method in higher education are made; it acts as an effective means of forming the future primary school teacher's methodological competence, developing his or her cognitive interest, autonomy, intellectual abilities, forming professionally important personality traits. It enables each student to engage in an active cognitive process, to identify abilities in group collaboration, and to increase motivation for learning.

Key words: students' methodological training, improvement of primary school teachers' training; forming primary schoolchildren's subject competence in Nature Study; teacher of higher educational institution; methodological competence of primary school teacher of Nature Study; New Ukrainian school; project method of teaching; creative personality; development of student personality; competency education; technological map of the project activity.

\section{REFERENCES (TRANSLATED AND TRANSLITERATED)}

1. Victorenko, I. (2017). Primary school teacher's methodological competence in teaching Nature Studies to primary schoolchildren. Theoretical aspect. Spirituality of Personality: Methodology, Theory and Practice No. 2 (77), 52-61.

2. Curriculum for the $1-4$ forms. (n.d.). mon.gov.ua Retrieved from https://mon.gov.ua/ua/osvita/zagalna-serednya-osvita/navchalni-programi/navchalni-programi-dlyapochatkovoyi-shkoli.

3. New state standard of primary comprehensive education. (2017). Ukrainian August Conference. Retrieved from http://nus.org.ua/wp-content/uploads/2017/08/NewSchool_Presentationfinal_18-08-2017.pdf.

Матеріали надійшли до редакції 09.11.2018 р. 